\title{
PENGARUH GAYA KEPEMIMPINAN DEMOKRATIS DAN MOTIVASI TERHADAP KINERJA KARYAWAN PT.PANIN BANK CABANG ATMO PALEMBANG
}

\author{
Bronto Kesuma \\ PT. Panin Bank Cabang Atmo Palembang \\ Email : brantaoce1@gmail.com \\ Harun Syamsuddin \\ Program Magister Universitas IGM Palembang \\ Email : drharun@uigm.ac.id \\ DOI : 10.35908/jeg.v4i2.758
}

Received: June 07, 2019, Revised: June 22, 2019, Accepted: July 27, 2019

\begin{abstract}
This study aims to determine the effects of leadership style and motivation on Employee Performance PT. Panin Bank Cabang Atmo Palembang, either simultaneously or partialy. The hypothesis purpose It is suspected that there is an influence between the Democratic leadership style on the Employee Performance of PT. Panin Bank Atmo Branch Palembang. Allegedly there is an influence between Motivation on Employee Performance of PT. Panin Bank Atmo Branch Palembang. It is suspected that there is an influence between the Style of Democratic Leadership and Motivation simultaneously on the Employee Performance of PT. Panin Bank Atmo Branch Palembang. The study population was all employees of PT. Panin Bank Cabang Atmo Palembang which totaled 30 people, the study sample using sampling satured with details of the sample to be tested instrumen and sample data analysis by 37 respondens. From the discussion that has been described, then conclusions can be drawn as follows; The results of testing the research hypothesis there is an effect of Motivation on the Performance of employees of PT.Panin Bank Branch Atmo Palembang, the results of testing the hypothesis that there is no influence of the Democratic leadership style on the performance of employees of PT. Panin Bank Atmo Branch Palembang, and the results of testing the hypothesis that there is an influence between democratic leadership style and motivation together on the performance of employees of PT. Panin Bank Atmo Branch Palembang.
\end{abstract}

Keywords: Style of Democratic Leadership, Motivation and Performance

\begin{abstract}
ABSTRAK
Penelitian ini bertujuan untuk mengetahui Pengaruh Gaya Kepemimpinan Demokratis dan Motivasi Terhadap Kinerja Karyawan PT. Panin Bank Cabang Atmo Palembang, baik secara simultan maupun parsial. Hipotesis yang di ajukan Diduga terdapat pengaruh antara Gaya kepemimpinan Demokratis terhadap Kinerja Karyawan PT. Panin Bank Cabang Atmo Palembang. Diduga terdapat pengaruh antara Motivasi terhadap Kinerja Karyawan PT. Panin Bank Cabang Atmo Palembang. Diduga terdapat pengaruh antara Gaya Kepemimpinan Demokratis dan Motivasi secara simultan terhadap Kinerja Karyawan PT. Panin Bank Cabang Atmo Palembang. Populasi penelitian ini adalah seluruh karyawan PT. Panin Bank Cabang Atmo Palembang yang berjumlah 37 orang, sampel penelitian menggunakan Sampling Jenuh dengan perincian sampel untuk diuji coba instrumen dan sampel analisis data sebanyak 37 responden. Hasil pengujian hipotesis penelitian terdapat pengaruh Motivasi terhadap Kinerja karyawan PT.Panin Bank Cabang Atmo Palembang. Hasil pengujian Hipotesis bahwa Tidak terdapat pengaruh gaya kepemimpinan Demokratis terhadap kinerja karyawan PT.Panin Bank Cabang Atmo Palembang. Hasil pengujian Hipotesis bahwa terdapat pengaruh antara gaya kepemimpinan demokratis dan motivasi secara bersama-sama terhadap kinerja karyawan PT. Panin Bank Cabang Atmo Palembang.
\end{abstract}

Kata kunci : Gaya Kepemimpinan Demokratis, Motivasi dan Kinerja 


\section{Pendahuluan}

\subsection{Latar Belakang}

Tujuan organisasi dapat tercapai apabila kerjasama diantara para pelaku organisasi berjalan dengan lancar. Seorang Pimpinan tidak akan dapat mengendalikan situasi organisasi tanpa adanya kerjasama yang baik dengan bawahannya. Dalam memberikan tugasnya seorang pemimpin terkadang menghadapi berbagai tingkah laku pegawai dalam menghadapi pekerjaannya. Diantaranya pegawai yang cepat tanggap dalam melaksanakan tugasnya, pegawai yang tidak mau atau tidak bisa melaksanakan pekerjaan, dan pegawai yang acuh dalam menyelesaikan tugasnya dengan baik, sesuai dengan yang diharapkan oleh organisasi.

PT. Panin Bank cabang Atmo Palembang Sebagai perusahaan yang bergerak di bidang perbankan dan jasa keuangan, memiliki banyak pesaing. Dunia perbankan di Indonesia sangat kompetitif, terlihat dari banyaknya bank yang berdiri dan membuka cabang di seluruh Indonesia baik bank nasional maupun bank asing. Bank-bank tersebut berusaha menarik nasabah dan senantiasa berusaha meningkatkan eksistensinya guna mendapat kepercayaan dari para nasabahnya terhadap bank tersebut. Seluruh perusahaan perbankan tersebut terus berinovasi dan berkembang, tentunya dengan mempersiapkan segala konsekuensi yang mungkin saja bisa terjadi. Salah satunya menciptakan lingkungan kerja yang baik, ditambah dengan gaya kepemimpinan yang baik yang akhirnya akan mempengaruhi motivasi kerja dari karyawan guna meningkatkan kinerja karyawan tersebut. Atasan harus dapat memberi kontrol yang baik, disiplin terhadap karyawannya dan dapat mengambil keputusan secara tegas.
Karena seorang pemimpin harus menjadi pemimpin yang baik bagi para karyawannya.

Beberapa tahun belakangan ini, perekonomian dan keuangan dunia sedang mengalami pelemahan, dan itu berdampak negatif pada banyak sektor termasuk yang terkena imbasnya adalah dari sektor perbankan. Mengantisipasi hal tersebut, PT Panin Bank Cabang Atmo Palembang tetap berusaha semaksimal mungkin untuk tetap menjaga konsistensinya dengan meningkatkan kualitas dan kuantitas sistem perbankannya. Hal itu dilakukan guna tetap mendapat kepercayaan dari para nasabah. Sumber daya manusia sangat berperan besar sebagai pelaku ekonomi.

Dengan model Gaya Kepemimpinan Demokratis diharapkan mampu mendorong perkembangan dan kemajuan perusahaan sehingga bisa tetap konsisten dan eksis sampai saat ini, namun dalam perkembangannya model gaya kepemimpinan demokratis dan motivasi yang ada belum mampu membantu menjaga konsistensi kinerja dari para karyawannya. Dapat dilihat pada gambar 1.1 mengenai Grafik Kinerja yang selalu mengalami fluktuasi selama 3 tahun terakhir pada setiap posisi jabatan.

\section{Gambar1.1}

Kinerja PT. Panin Bank Cab. Atmo Palembang Tahun 2014-2016

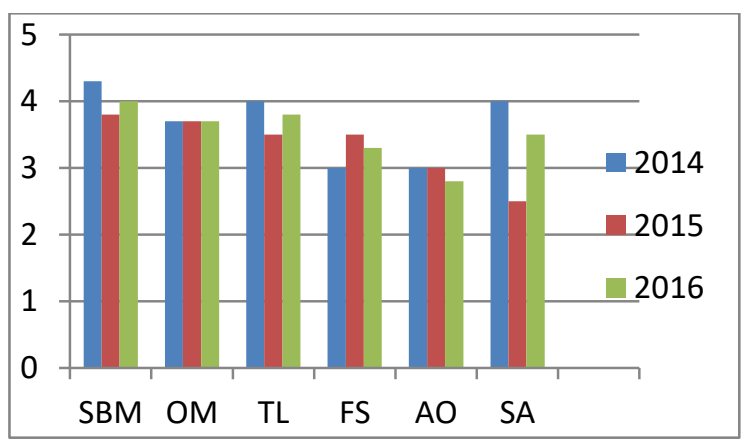

Sumber: PT. Panin Bank Cabang Atmo Palembang 
Dari gambar kinerja di atas terlihat adanya fluktuasi terhadap pencapaian kerja pada tiap bagian, hanya OM (Operation Manager) yang tetap stabil, selebihnya selalu mengalami fluktuasi tiap tahunnya. Penurunan yang cukup drastis terlihat pada bagian SA(Service Assistant) di tahun 2016 dan bagian AO (Account Officer) pada tahun 2016 yang mendapat rating di bawah 3 yang berarti berpredikat cukup. Perusahaan menargetkan pada tiap bagian mampu mencapai rating minimal 3 yaitu dalam Predikat baik. Meskipun begitu, nyatanya rating 3 dengan predikat baik yang sudah mampu diraih tiap bagian belum mampu dijaga kestabilannya sehingga fluktuasi masih selalu terjadi tiap tahunnya.

Dilihat dari Gambar yang kinerja yang selalu mengalami fluktuasi dan tidak pernah stabil mengindikasikan adanya penurunan kinerja karyawan, hal itu juga merujuk pada model gaya kepemimpinan Demokratis yang diterapkan masih lemah. Karena seharusnya spesifik dari gaya kepemimpinan demokratis adalah menyesuaikan kesiapan pada diri karyawan sehingga mampu menimbulkan motivasi kerja karyawan dan meningkatkan kinerja karyawan.

Dari fenomena di atas, tergambar bahwa Kinerja PT. Panin Bank cabang Atmo Palembang dalam 3 tahun terakhir, telah berjalan dengan baik. Akan tetapi Kinerja SA dan AO masih rendah. Hal ini diduga karena dipengaruhi oleh Gaya Kepemimpinan dan Motivasi.

Motivasi kerja juga tidak kalah pentingnya dalam upaya mendorong pegawai dalam melaksanakan tugas dan pekerjaannya sehingga dapat berjalan lancar. Oleh karena itu maka seseorang pemimpin harus berusaha untuk membuat iklim kerja yang kondusif sehingga para pegawai lebih berprestasi untuk bekerja dan berfikir kreatif. Seorang pemimpin harus dapat mempelajari karakter pegawaimya sehingga dapat mengevaluasi dirinya dan mengetahui apakah gaya kepemimpinannya telah sesuai dengan kemauan, kemampuan maupun harapan pegawai karena gaya kepemimpinan dan motivasi kerja yang sesuai dengan harapan akan memberikan peran besar dalam kemajuan suatu organisasi.

PT. Panin Bank Cabang Atmo Palembang dalam jangka waktu tertentu, Pemimpin dalam tiap unit-unit cabang pembantu terlalu lama dilakukan rolling jabatan, yang mana setiap pemimpin cabang memiliki gaya kepemimpinan berbeda. Dimana setiap gaya kepemimpinan memiliki dampak positif maupun negatif atas kinerja karyawan dimana zaman globalisasi sekarang ini tentunya kebutuhan setiap karyawan akan semakin bertambah seiring perkembangan zaman.

Alasan yang menjadi dasar dalam penelitian ini adalah bahwa sumber daya manusia menduduki peran yang cukup penting di dalam suatu perusahaan. Dengan adanya gaya kepemimpinan yang baik dari pemimpin dan motivasi kerja yang tinggi diharapkan dapat meningkatkan kinerja yang baik. Dengan adanya kinerja yang baik dari karyawan , maka akan terjadi peningkatan pelayanan pada PT. Panin Bank Cabang Atmo palembang, sehingga akan meningkatkan kualitas perusahaan. Hal ini menjadikan PT.Panin Bank Cabang Atmo untuk lebih memperhatikan faktor-faktor Gaya kepemimpinan, motivasi kerja yang baik sehingga membuat karyawan memiliki 
semangat kerja yang tinggi serta ulet dalam bekerja, sehingga akan memberikan kontribusi yang positif terhadap perusahaan. Dengan adanya kontribusi tersebut diharapkan dapat tercapainya maksud dan tujuan PT. Panin Bank Cabang Atmo palembang.

Berdasarkan fenomena diatas menunjukan bahwa PT. Panin Bank Cabang Atmo Palembang dimana gaya kepemimpinan Demokratsis yang ada belum sesuai, pemimpin selalu menilai mampu dan bisa kepada para karyawannya dalam menyelesaikan pekerjaan tanpa melihat sumber daya manusia dan lingkungan setempatnya. Motivasi kerja yang kurang mengakibatkan menurunnya kinerja karyawan.

\subsection{Rumusan Masalah}

Adapun masalah yang akan diselesaikan dalam penelitian ini adalah sebagai berikut :

1. Apakah Gaya Kepemimpinan Demokratis berpengaruh terhadap kinerja karyawan PT. Panin Bank Cabang Atmo Palembang ?

2. Apakah Motivasi berpengaruh terhadap kinerja karyawan PT. Panin Bank Cabang Atmo Palembang?

3. Apakah Gaya Kepemimpinan Demokratis dan motivasi secara bersama-sama berpengaruh terhadap kinerja karyawan PT. Panin Bank Cabang Atmo Palembang?

\subsection{Tujuan Penelitian}

Tujuan yang diinginkan pada penelitian ini adalah untuk mengetahui dan menganalisis pengaruh: a. Gaya kepemimpinan Demokratis terhadap kinerja karyawan PT. Panin Bank Cabang Atmo Palembang

b. Motivasi terhadap kinerja karyawan PT. Panin Bank Cabang Atmo Palembang

c. Gaya kepemimpinan Demokratis dan motivasi secara bersama-sama terhadap kinerja karyawan PT. Panin Bank Cabang Atmo Palembang

\subsection{Metodologi Penelitian}

Untuk memperoleh gambaran karakterisitik yang menyeluruh terhadap populasi yang diteliti, diperlukan analisis deskriftif. Analisis data dilakukan terhadap jawaban responden terhadap setiap butir pertanyaan dari setiap variable yang diteliti. Setelah dilakukan tabulasi terhadap setiap butir pertanyaan pada variabel yang diteliti, maka dilakukan analisis deskriftif. Analisis statistik deskriftif dilakukan dengan menggunakan analisi distribusi frekuensi populasi. Distribusi frekuensi poppulasi dala statistik deskriftif meliputi: range, mean, median, standar deviasi, kuartil, desil dan dilengkapi dengan grafik atau diagram. Dengan dilakukan analisis statitsik deskriftif diharapkan temuantemuan dalam penelitian secara deskriptif dapat disajikan dan dibaca lebih mudah, sehingga dapat memperkaya analisis dalam menyimpulkan hasil penelitian dan memberikan saran-saran atau implikasi kebijakan.

Model regresi yang digunakan adalah regresi berganda, yaitu untuk mengukur pengaruh variabel gaya kepemimpinan demokratis dan motivasi secara bersama-sama terhadap kinerja (Y) dengan rumus :

$$
\mathrm{Y}=\mathrm{a}+\mathrm{b}_{1} \mathrm{X}_{1}+\mathrm{b}_{2} \mathrm{X}_{2}
$$


Dimana :

$$
\begin{array}{ll}
\mathrm{Y} & =\text { variabel kinerja } \\
\mathrm{a} & =\text { konstanta } \\
\mathrm{b}_{1}, \mathrm{~b}_{2}= & \text { koefisien regresi } \\
\mathrm{X}_{1}= & \text { variabel gaya kepemimpinan } \\
& \text { demokratis } \\
\mathrm{X}_{2} & =\text { variabel motivasi }
\end{array}
$$

\section{Pemahaman}

\subsection{Kepemimpinan}

Kepemimpinan memegang peranan yang sangat penting dalam manajemen organisasi. Kepemimpinan dibutuhkan manusia karena adanya keterbatasanketerbatasan tertentu pada diri manusia. Dari sinilah timbul kebutuhan untuk dipimpin dan memimpin. Kepemimpinan didefinisikan ke dalam ciri-ciri individual, kebiasaan, cara mempengaruhi orang lain, interaksi, kedudukan dalam organisasi dan perespsi mengenai pengaruh yang sah. Menurut Arep dan Tanjung (2002:235) menerangkan bahwa "Kepemimpinan adalah kemampuan seseorang untuk menguasai atau mempengaruhi orang lain atau masyarakat yang saling berbeda-beda menuju kepada pencapaiaan tujuan tertentu“. Robbins (2006:432) menyatakan kepemimpinan adalah kemampuan untuk mempengaruhi kelompok menuju pencapaian sasaran. Kartono (2005:153) menyatakan kepemimpinan adalah kemampuan untuk memberikan pengaruh yang konstruktif kepada orang lain untuk melakukan suatu usaha kooperatif mencapai tujuan yang sudah direncanakan.

\subsection{Gaya Kepemimpinan Demokratis}

Bahwasannya pemimpin dalam memengaruhi pengikutnya mempunyai gaya atau style yang berbeda-beda antara yang satu dengan yang lainnya. Gaya kepemimpinan atau leadership style, menurut Fred Luthan (Wirawan, 2003 : 80) adalah "The word style is roughtly equalent to the way leader influence that style may be influenced by culture" kepemimpinan adalah cara pemimpin mempengaruhi para pengikut dan gaya kepemimpinan dipengaruhi oleh budaya.

Sementara itu menurut Wirawan (2003: 80), gaya kepemimpinan itu adalah sebagai pola perilaku pemimpin dalam mempengaruhi para pengikutnya. Pengertian perilaku disni tidak dalam artian statis, karena gaya kepemimpinan seseorang dapat berubah-ubah tergantung pengikut dan situasinya. Dengan kata lain, seorang pemimpin dapat mempergunakan sejumlah pola perilaku yang berbeda dalam mempengaruhi para pengikutnya.

Winardi (2000:78) mengemukakan gaya kepemimpinan demokratis adalah kepemimpinan yang aktif, dinamis, dan terarah. Kegiatan pengendalian dilaksanakan secara tertib dan bertanggungjawab. Pembagian tugas yang disertai pelimpahan wewenang dan tanggung jawab yang jelas, memungkinkan setiap anggota berpartisipasi secara aktif. Dengan katalain, setiap anggota mengetahui secara pasti sumbangan yang dapat diberikannya untuk mencapai tujuan kelompok atau organisasinya. Selain itu dapat diketahui bagaimana melaksanakannya secara efektif dan efisien.

Gaya Kepemimpinan mengandung arti kemampuan mempengaruhi, menggerakkan, dan mengarahkan suatu tindakan pada diri seseorang atau sekelompok orang untuk mencapai tujuan 
tertentu pada situasi tertentu (Abi Sujak, 2000:56). Dengan demikian dari seorang pemimpin dapat berpengaruh terhadap kinerja.

\subsection{Pengertian Motivasi}

Motivasi berasal dari kata dalam bahasa latin yakni movere yang berarti dorongan atau menggerakkan. Semua perilaku manusia biasanya didasari akan motivasi atau dorongan dalam banyak hal yang menyebabkan mereka berperilaku demikian. Pada manajemen, motivasi adalah hal yang menyebabkan semua anggota organisasi untuk bekerja dalam menyelesaikan pekerjaan yang sesuai motif atau tujuan organisasi atau perusahan yang ingin dicapai.

Menurut Siagian dalam Kartika (2010:102) definisi dari motivasi adalah keseluruhan proses pemberian motif bekerja kepada para bawahan sedemikian rupa sehingga mereka mau bekerja dengan ikhlas demi tercapainya tujuan organisasi dengan efisien dan ekonomis. As'ad dalam Roesyadi (2012:24) mengemukakan bahwa motivasi sering sekali diartikan sebagai dorongan.

\subsection{Kinerja Karyawan}

Istilah Kinerja digunakan untuk mengukur hasil yang telah dicapai sehubungan dengan kegitan atau aktivitas perusahaan, apakah kinerja perusahaan telah baik atau perlu adanya evaluasi-evaluasi kebelakang mengenai hasil yang dicapai.

Kinerja dalam organisasi merupakan jawaban dari berhasil atau tidaknya tujuan organisasi yang telah ditetapkan. Para atasan atau manajer sering tidak memerhatikan kecuali sudah amat buruk atau segala sesuatu jadi serba salah. Terlalu sering manajer tidak mengetahui betapa buruknya kinerja telah merosot sehingga perusahaan/instansi menghadapi krisis yang serius. Kesan-kesan buruk organisasi yang mendalam berakibat dan mengabaikan tanda-tanda peringatan adanya kinerja yang merosot.

Kinerja sebagai hasil-hasil fungsi pekerjaan/atau kegiatan seseorang atau kelompok dalam suatu organisasi yang di pengaruhi oleh berbagai faktor untuk mencapai tujuan organisasi dalam periode waktu tertentu (Tika, 2006:26).

\subsection{Penelitian Terdahulu}

Adanya penelitian-penelitian sejenis yang telah dilakukan sebelumnya berperan sangat penting dalam sebuah penelitian yang akan dilakukan.

Penelitian Angga Saputra (2008) tentang Pengaruh disiplin kerja dan Gaya Kepemimpinan terhadap kinerja pegawai PT.Exa Mandiri Solusi Palembang, dimana ia mengatakan bahwa terdapat pengaruh gaya kepemimpinan terhadap kinerja pegawai dengan persamaan linier $\mathrm{Y}=17,147+0,748 \quad \mathrm{X} 2, \quad$ dimana Gaya Kepemimpinan memiliki koofesien sebesar 0,748 maka dinyatakan bahwa setiap penambahan satu-satuan jumlah gaya kepemimpinan akan meningkatkan kinerja pegawai 0,748 .

Rio Saputra (2006) hasil penelitiannya tentang Pengaruh Gaya Kepemimpinan dan motivasi terhadap Produktivitas kerja PT.Kurnia Maju Sejahtera Palembang mengatakan baahwa terdapat pengaruh Motivasi terhadap Produktivitas kerja dengan persamaan linier $\mathrm{Y}=41,262+0,761 \quad \mathrm{X} 2$. Hasil diperoleh koefesien determinasi variable 
(R2) 0,413 , maka 41,3\% variasi nilai skor produktivitas kerja dipengaruhi oleh motivasi dan sisanya $58,7 \%$ dijelaskan oleh faktor lain.

Darwito, SE (2008) dalam hasil penelitiannya tentang Pengaruh Gaya Kepemimpinan terhadap kepuasan Kerja dan Komitmen Organisasi untuk Meningkatkan Kinerja Karyawan (Studi pada RSUD Kota Semarang). Hasil ini menunjukkan diantaranya bahwa gaya kepemimpinan berpengaruh positif terhadap kepuasan kerja. Kepuasan kerja berpengaruh positif terhadap kinerja karyawan. Gaya kepemimpinan berpengatuh positif terhadap komitmen organisasi. Komitmen organisasi berpengaruh positif terhadap kinerja karyawan. Gaya kepemimpinan berpengaruh positif terhadap kinerja karyawan.

\section{Hasil Dan Pembahasan}

\subsection{Populasi dan Sampel}

\subsubsection{Populasi}

Populasi adalah wilayah generalisasi yang terdiri dari atas objek/subjek yang mempunyai kualitas dan karakteristik tertentu yang ditetapkan oleh peneliti untuk dipelajari dan kemudian ditarik kesimpulannya (Sugiyono: 2005). Dari pengertian tersebut, maka yang menjadi populasi dalam penelitian ini adalah Seluruh karyawan PT. Panin Cabang Atmo Palembang yang berjumlah 37 orang.

\subsubsection{Sampel}

Sampel adalah bagian dari populasi yang mewakili populasi yang akan diambil (Notoatmojo, 2005). Sampel dalam penelitian ini adalah semua karyawan PT. Panin Bank Cabang Atmo Palembang, yaitu berjumlah 37 orang.

\subsection{Uji Asumsi Klasik}

\subsubsection{Uji normalita}

Uji normalitas ini dilakukan dengan menggunakan SPSS 24.0. Di dapat hasil seperti grafik 4.1. berikut ini:

\section{Grafik 4.1}

Hasil Uji Normalitas (Histrogram)

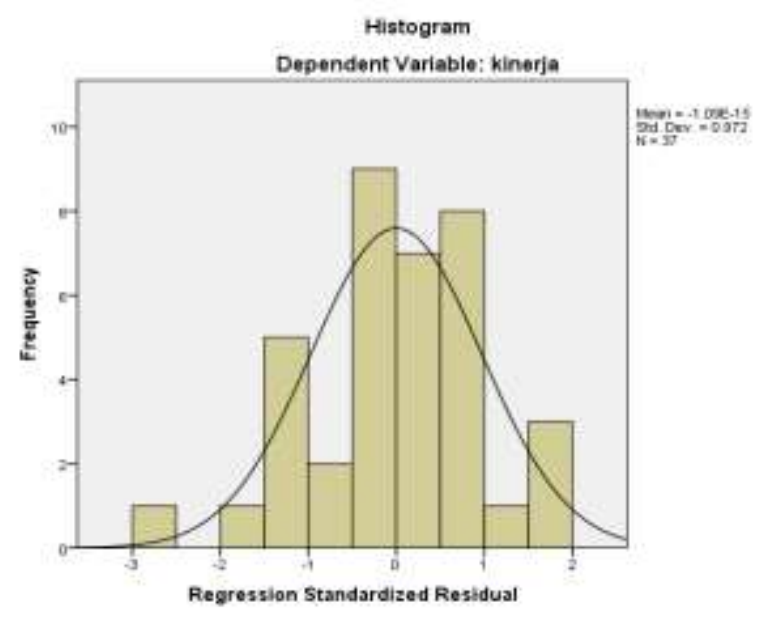

Sumber: Data Primer diolah dengan SPPS, 2017

Dari grafik 4.1 di atas, bahwa penyebaran data telah mengikuti arah garis diagonal, sehingga data telah berdistribusi normal, tidak ada data-data yang menyimpang. Maka model regresi telah layak dan memenuhi distibusi normal.

\subsubsection{Uji Multikoliniearitas}

Uji ini bertujuan untuk menguji apakah model regresi ditemukan adanya korelasi antar variabel independen. 
Tabel 3.1

Hasil Uji Multikolinearitas

\begin{tabular}{|c|c|c|c|c|c|c|c|c|}
\hline \multicolumn{9}{|c|}{ Coefficients $^{a}$} \\
\hline & \multirow{2}{*}{ Model } & \multicolumn{2}{|c|}{$\begin{array}{l}\text { Unstandardized } \\
\text { Coefficients }\end{array}$} & \multirow{2}{*}{$\begin{array}{c}\text { Standardized } \\
\text { Coefficients }\end{array}$} & \multirow{2}{*}{$\mathrm{t}$} & \multirow{2}{*}{ Sig. } & \multicolumn{2}{|c|}{ Collinearity Statistics } \\
\hline & & $\mathrm{B}$ & Std. Error & & & & Tolerance & VIF \\
\hline \multirow[t]{3}{*}{1} & (Constant) & 19.833 & 4.090 & & 4.849 & .000 & & \\
\hline & motivasi & .465 & .116 & .803 & 4.009 & .000 & .489 & 2.044 \\
\hline & kepemimpinan & -.335 & .153 & -.440 & -2.197 & .035 & .489 & 2.044 \\
\hline
\end{tabular}

Sumber: Data Primer diolah dengan SPPS, 2017

Berdasarkan output pada tabel di atas diketahui bahwa nilai tolerance dari ke dua variabel independen lebih besar dari 0.10 dan nilai VIF dari ke tujuh variabel independen lebih kecil dari 10.00 sehingga berdasarkan nilai di atas dapat disimpulkan bahwa tidak terjadi multikolinearitas.

\subsubsection{Uji Heteroskedastisitas}

Uji Heteroskedastisitas bertujuan untuk menguji apakah dalam model regresi terjadi ketidaksamaan variance dari residual suatu pengamatan kepengamatan lainnya. Pengujian ini menggunakan SPSS 24.0 dengan hasil sebagai berikut:

\section{Grafik 3.2}

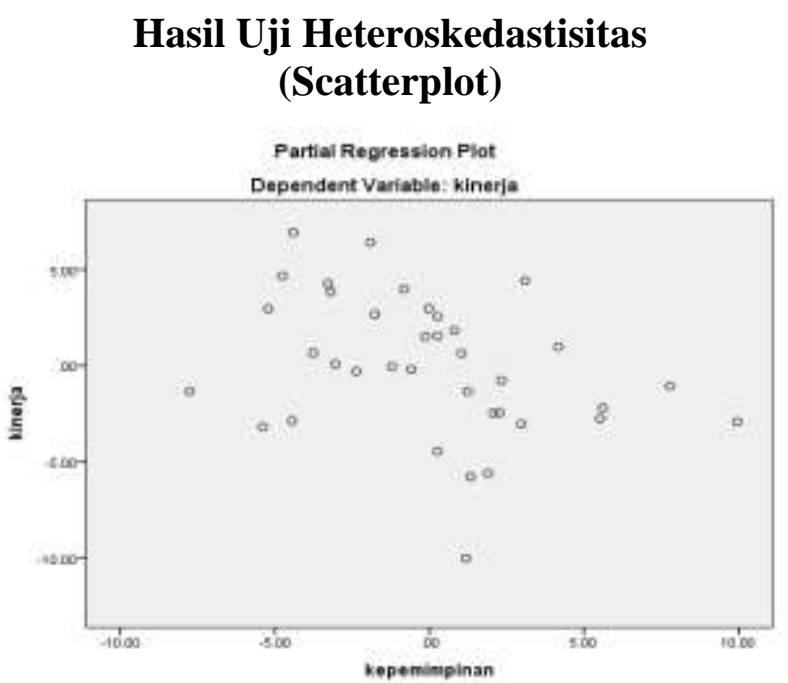

Sumber: Data Primer diolah dengan SPPS, 2017
Dasar analisa uji heteroskodesitas dengan grafik plot adalah jika titik dalam grafik tersebar (tidak membentuk pola) maka tidak terjadi heteroskodesitas.

\subsection{Pengujian Hipotesis}

\subsubsection{Uji F ( Pengujian Hipotesis)}

Untuk menguji pengaruh variabel bebas secara bersama-sama diuji dengan menggunakan uji F. Hasil perhitungan regresi secara simultan diperoleh sebagai berikut:

Tabel 3.2

Hasil Analisis Regresi

\begin{tabular}{|c|c|c|c|c|c|c|}
\hline \multicolumn{7}{|c|}{$\mathrm{ANOVA}^{\mathbf{a}}$} \\
\hline & Model & $\begin{array}{l}\text { Sum of } \\
\text { Squares }\end{array}$ & df & $\begin{array}{c}\text { Mean } \\
\text { Square }\end{array}$ & $\mathbf{F}$ & Sig. \\
\hline \multirow[t]{3}{*}{1} & Regression & 206.050 & 2 & 103.025 & 8.494 & $.001^{b}$ \\
\hline & Residual & 412.383 & 34 & 12.129 & & \\
\hline & Total & 618.432 & 36 & & & \\
\hline \multicolumn{7}{|c|}{ a. Dependent Variable: kinerja } \\
\hline \multicolumn{7}{|c|}{ b. Predictors: (Constant), kepemimpinan, motivasi } \\
\hline
\end{tabular}

Sumber: Data Primer diolah dengan SPPS, 2017

Pengujian pengaruh variabel bebas secara bersama-sama terhadap variable terikatnya dilakukan dengan menggunakan 
uji F. Hasil perhitungan statistic menunjukkan nilai $\mathrm{F}$ hitung $=8,494$ Dengan menggunakan batas signifikansi 0,05, maka diperoleh nilai signifikansi tersebut lebih kecil dari 0,05. Hal ini berarti bahwa hipotesis yang menyatakan bahwa variabel gaya kepemimpinan, dan motivasi mempunyai pengaruh terhadap kinerja karyawan.

\subsubsection{Koefisien Determinasi $\left(\mathbf{R}^{2}\right)$}

Koefisien determinasi merupakan besaran yang menunjukkan besarnya variasi variabel dependen yang dapat dijelaskan oleh variabel independennya. Dengan kata lain, koefisien determinasi ini digunakan untuk mengukur seberapa jauh variable variabel bebas dalam menerangkan variabel terikatnya. Nilai koefisien determinasi ditentukan dengan nilai adjusted $R$ square sebagaimana rapat dilihat pada tabel 3.3

\section{Tabel 3.3}

\section{Koefisien determinasi}

Model Summary ${ }^{b}$

\begin{tabular}{|c|c|c|c|c|}
\hline Model & $\mathbf{R}$ & R Square & $\begin{array}{c}\text { Adjusted } \\
\text { R Square }\end{array}$ & $\begin{array}{c}\text { Std. Error of } \\
\text { the Estimate }\end{array}$ \\
\hline 1 & $.577^{\mathrm{a}}$ & .333 & $\mathbf{. 2 9 4}$ & 3.48266 \\
\hline \multicolumn{5}{|c|}{ a. Predictors: (Constant), kepemimpinan, motivasi } \\
\hline \multicolumn{3}{|l}{ b. Dependent Variable: kinerja } \\
\hline
\end{tabular}

Sumber: Data Primer diolah dengan SPPS, 2017

Hasil perhitungan regresi dapat diketahui bahwa koefisien determinasi (adjusted R2) yang diperoleh sebesar 0,294. Hal ini berarti $29 \%$ variasi variabel kinerja karyawan dapat dijelaskan oleh variabel gaya kepemimpinan demokratis dan motivasi, sedangkan sisanya sebesar $71 \%$ diterangkan oleh variabel lain yang tidak diajukan dalam penelitian ini.

\subsubsection{Uji $T$ (Uji Hipotesis Secara Parsial)}

Hipotesis 1, 2 dan 3 dalam penelitian ini diuji kebenarannya dengan menggunakan uji parsial. Pengujian dilakukan dengan melihat taraf signifikansi (pvalue), jika taraf signifikansi yang dihasilkan dari perhitungan di bawah 0,05 maka hipotesis diterima, sebaliknya jika taraf signifikansi hasil hitung lebih besar dari 0,05 maka hipotesis ditolak.

Tabel 3.4.

\section{Hasil Uji t Secara Parsial \\ Coefficients $^{\mathrm{a}}$}

\begin{tabular}{|c|c|c|c|c|c|c|}
\hline \multirow[b]{2}{*}{ Model } & \multicolumn{3}{|c|}{ Unstandardized Coefficients } & $\begin{array}{l}\text { Standardized } \\
\text { Coefficients }\end{array}$ & $\mathbf{t}$ & Sig. \\
\hline & \multicolumn{2}{|l|}{ B } & $\begin{array}{l}\text { Std. } \\
\text { Error }\end{array}$ & Beta & & \\
\hline \multirow[t]{3}{*}{1} & (Constant) & 19.833 & 4.090 & & 4.849 & .000 \\
\hline & motivasi & .465 & .116 & .803 & 4.009 & .000 \\
\hline & kepemimpinan & -.335 & .153 & -.440 & -2.197 & .035 \\
\hline \multicolumn{7}{|c|}{ a. Dependent Variable: kinerja } \\
\hline
\end{tabular}

\subsubsection{Uji Hipotesis 1 ( H1 )}

Perumusan hipotesis:

Ho : $\beta \mathrm{i}=0$ tidak ada pengaruh positif antara gaya kepemimpinan demokratis dengan kinerja karyawan.

$\mathrm{Ha}: \beta \mathrm{i}>0$ terdapat pengaruh positif antara gaya kepemimpinan dengan kinerja karyawan.

Dari tabel 3.4.terlihat bahwa hasil pengujian hipotesis gaya kepemimpinan menunjukkan nilai $t$ hitung negative sebesar -,2.197 dengan taraf signifikansi 0,035 . Taraf signifikansi tersebut lebih kecil dari 0,05, yang berarti bahwa hipotesis dalam penelitian ini menolak Ho dan menerima Ha. Dengan demikian berarti bahwa hipotesis $\mathrm{H}_{1}$ "Gaya Kepemimpinan Demokratis mempunyai 
pengaruh Negatif terhadap Kinerja karyawan" diterima.

\subsubsection{Uji Hipotesis 2 ( H2 )}

Perumusan hipotesis:

Ho $: \beta \mathrm{i}=0$ tidak ada pengaruh positif antara motivasi kerja dengan kinerja karyawan.

$\mathrm{Ha}: \beta \mathrm{i}>\quad 0$ terdapat pengaruh positif antara motivasi kerja dengan kinerja karyawan.

Dari tabel 3.4.terlihat bahwa hasil pengujian hipotesis motivasi menunjukkan nilai t hitung sebesar 4,009 dengan taraf signifikansi 0,000. Taraf signifikansi hasil sebesar 0,000 tersebut lebih kecil dari 0,05 , yang berarti bahwa hipotesis dalam penelitian ini menerima $\mathrm{Ha}$ dan menolak Ho. Dengan demikian berarti bahwa hipotesis $\mathrm{H}_{2}$ "Motivasi berpengaruh positif terhadap Kinerja karyawan" diterima.

\subsubsection{Uji Hipotesis 3 ( $\mathrm{H3}$ )}

Perumusan hipotesis:

Ho $: \beta \mathrm{i}=0$ tidak ada pengaruh positif antara motivasi kerja dengan kinerja karyawan.

$\mathrm{Ha}: \beta \mathbf{i}>\quad 0$ terdapat pengaruh positif antara motivasi kerja dengan kinerja karyawan.

Dari tabel 3.4.terlihat bahwa hasil pengujian hipotesis motivasi menunjukkan nilai t hitung sebesar 4,849 dengan taraf signifikansi 0,000 . Taraf signifikansi hasil sebesar 0,000 tersebut lebih kecil dari 0,05 , yang berarti bahwa hipotesis dalam penelitian inimenerima $\mathrm{Ha}$ dan menolak Ho. Dengan demikian berarti bahwa hipotesis $\mathrm{H}_{3} \quad$ "Gaya Kepemimpinan Demokratis dan Motivasi secara bersamasama berpengaruh positif terhadap Kinerja karyawan" diterima.
Berdasarkan hasil pengujian secara statistik dapat terlihat dengan jelas bahwa secara parsial (individu) semua variabel bebas berpengaruh terhadap variabel terikat. Pengaruh yang diberikan keduaa variabel bebas tersebut bersifat positif artinya semakin tinggi gaya kepemimpinan demokratis dan motivasi maka mengakibatkan semakin tinggi pula kinerja karyawan yang dihasilkan. Hasil tersebut sesuai dengan hipotesis yang diajukan. Hasil penelitian ini juga sesuai dengan hasil penelitian sebelumnya. Penjelasan dari masing-masing pengaruh variabel dijelaskan sebagai berikut:

\subsubsection{Pengaruh Gaya Kepemimpinan terhadap Kinerja Karyawan}

Hasil pengujian hipotesis $\left(\mathrm{H}_{1}\right)$ telah membuktikan terdapat pengaruh antara gaya kepemimpinan terhadap kinerja karyawan. Melalui hasil perhitungan yang telah dilakukan diperoleh nilai t hitung negative sebesar -2.197 dengan taraf signifikansi hasil sebesar 0,035 tersebut lebih kecil dari 0,05, dengan demikian $\mathrm{Ha}$ diterima dan Ho ditolak. Pengujian ini secara statistik membuktikan bahwa gaya kepemimpinan Demokratis berpengaruh negative signifikan terhadap kinerja karyawan. Artinya bahwa ada pengaruh antara variabel gaya kepemimpinan demokratis terhadap kinerja karyawan di PT. Panin Bank Cabang Atmo Palembang. Hasil ini mendukung penelitian sebelumnya oleh (Angga Saputra, 2008) yang menguji pengaruh gaya kepemimpinan terhadap kinerja karyawan dengan hasil analisis yaitu gaya kepemimpinan mempunyai pengaruh positif dan signifikan terhadap kinerja karyawan. 


\subsubsection{Pengaruh Motivasi terhadap Kinerja Karyawan}

Hasil pengujian hipotesis $\left(\mathrm{H}_{2}\right)$ telah membuktikan terdapat pengaruh antara motivasi terhadap kinerja karyawan. Melalui hasil perhitungan yang telah dilakukan diperoleh nilai t hitung sebesar 4.009 dengan taraf signifikansi hasil sebesar 0,000 tersebut lebih kecil dari 0,05, yang berarti bahwa hipotesis dalam penelitian ini menerima $\mathrm{Ha}$ dan menolak Ho. Pengujian ini secara statistik membuktikan bahwa motivasi berpengaruh positif terhadap kinerja karyawan. Artinya bahwa ada pengaruh antara variabel motivasi terhadap kinerja karyawan di PT. Panin Bank Cabang Atmo Palembang.Hasil ini mendukung penelitian sebelumnya oleh (Kristina Nugi Keran, 2012) yang menyatakan bahwa ada pengaruh positif dan signifikan antara motivasi terhadap kinerja karyawan.

\subsubsection{Pengaruh Gaya Kepemimpinan Demokratis dan Motivasi terhadap Kinerja Karyawan}

Hasil pengujian hipotesis $\left(\mathrm{H}_{3}\right)$ telah membuktikan terdapat pengaruh antara gaya kepemimpinan dan motivasi terhadap kinerja karyawan. Melalui hasil perhitungan yang telah dilakukan diperoleh nilai $\mathrm{t}$ hitung sebesar 4.849 dengan taraf signifikansi hasil sebesar 0,000 tersebut lebih kecil dari 0,05, yang berarti bahwa hipotesis dalam penelitian ini menerima $\mathrm{Ha}$ dan menolak Ho. Pengujian ini secara statistik membuktikan bahwa gaya kepemimpinan dan motivasi secara bersama-sama berpengaruh positif terhadap kinerja karyawan. Artinya bahwa ada pengaruh antara variabel gaya kepemimpinan dan motivasi terhadap kinerja karyawan di PT. Panin Bank
Cabang Atmo Palembang. Hasil ini mendukung penelitian sebelumnya oleh (Angga Saputra, 2006) yang menyatakan bahwa ada pengaruh positif dan signifikan antara gaya kepemimpinan dan motivasi terhadap kinerja karyawan.

\section{Kesimpulan}

\subsection{Kesimpulan}

Dari pembahasan yang telah diuraikan, maka dapat ditarik kesimpulan sebagai berikut:

1. Hasil pengujian hipotesis penelitian terdapat pengaruh Motivasi terhadap Kinerja karyawan PT.Panin Bank Cabang Atmo Palembang.

2. Hasil pengujian Hipotesis bahwa Tidak terdapat pengaruh gaya kepemimpinan Demokratis terhadap kinerja karyawan PT.Panin Bank Cabang Atmo Palembang.

3. Hasil pengujian Hipotesis bahwa terdapat pengaruh antara gaya kepemimpinan demokratis dan motivasi secara bersama-sama terhadap kinerja karyawan PT. Panin Bank Cabang Atmo Palembang.

\subsection{Implikasi Manajerial}

Upaya meningkatkan motivasi dapat memberikan suasana lingkungan kerja mendukung untuk kenyamanan karyawan dalam bekerja dan sesama karyawan agar saling membantu karyawan lain apabila ada karyawan yang mengalami kesulitan dalam melakukan dan 
menyelesaikan pekerjaannya agar mencapai hasil kerja yang baik.

$$
\text { Upaya untuk meningkatkan }
$$

Kinerja Karyawan PT. Panin Bank Cabang Atmo Palembang, dapat dilakukan dengan membangun lingkungan kerja yang mendukung kenyamanan kerja karyawan agar karyawan termotivasi untuk bekerja sama dalam menyelesaikan pekerjaan agar mencapai hasil kerja dengan baik.

\subsection{Saran}

Perlu dilakukan peninjauan dan evaluasi kepada Karyawan setiap tahunnya, agar karyawan dapat bekerja lebih baik lagi dengan sesama karyawan PT. Panin Cabang Atmo Palembang dengan baik dan lebih termotivasi agar hasil dan tujuan perusahaan dapat tercapai dengan baik pula.

\section{DAFTAR PUSTAKA}

Arep, Ishak dan,Tanjung, Hendri. 2002. Manajemen Sumber Daya Manusia. Jakarta: Universitas Trisakti.

Abdullah, Syukri, Nadirsyah, Safwan, 2014. Pengaruh Kompetensi Dan Motivasi Terhadap Kinerja Pengelolaan Keuangan Daerah Pada Pemerintah Daerah Kabupaten PIDIE Jaya, Jurnal Akuntansi Pascasarjana Universitas Syiah Kuala, Vol. 3 , No.1 2014, prodipps. unsyiah.ac.id. Di Download tanggal 10 Oktober 2016, Jam 11.00 WIB.

Afrizal, Andi, 2015. Pengaruh Gaya Kepemimpinan Terhadap Motivasi Kerja Dan Kepuasan Kerja Serta
Dampak Pada Kinerja Karyawan (Studi Kasus BMT Bina Ihsanul Fikri Yogyakarta), Volume V No. 2 Desember 2015/1436 H. Download katalog.pustaka.unand.ac.id. Di download tanggal 13 Oktober 2016, jam 13.30.WIB

Arikunto, Suharsini, 2002. Dasar-dasar Evaluasi Pendidikan. Jakarta : PT. Bumi Aksara.

Bangun, Wilson. 2012. Manajemen Sumber Daya Manusia. Bandung : Erlangga

Darwito, 2008. Pengaruh Gaya Kepemimpinan Terhadap Kepuasan Kerja dan komitmen Organisasi untuk meningkatkan Kinerja Karyawan Studi kasus pada RSUD Kota Semarang, https://www.researchgate.net.>pu blication. Di Download tanggal 10 Nopember 2016 jam 09.00 WIB.

Duwi. 2011. Uji Validitas Kuesioner (Online),(http://duwiconsultant.blo gspot.com/

2011/11/uji-validitas-

kuesioner.html/ diakses 14

November 2013)

Evanita, Leny. 2013. Disiplin, Gaya Kepemimpinan, Pelatihan Dan Kinerja Karyawan RSUD Lubuk Sikaping,

Repository.unej.ac.id $>$ bitstream $>h$ andel. Di download tanggal 26 Nopember 2016 jam. 15.00 WIB,

Firdaus, Zamzam Fakhry, 2018 Aplikasi Metodologi, Yogyakarta, Penerbit Deepublish

Gujarati, Damodar, 2003. Ekonometri Dasar. Terjemahan : Sumarno Zain. Jakarta: Erlangga. 
Ghozali, Imam. 2007. Aplikasi Analisis Multivariate Dengan Program SPSS. Semarang: Universitas Diponegoro

Handoko, T.H. 2001. Manajemen Personalia dan Sumber Daya Manusia. Jakarta : PT. Gramedia

Hasibuan, Malayu S.P. 2002. Manajemen Sumber Daya Manusia. Jakarta : Bumi Aksara

Hersey, Paul, Keneth Blanchard. 1992.

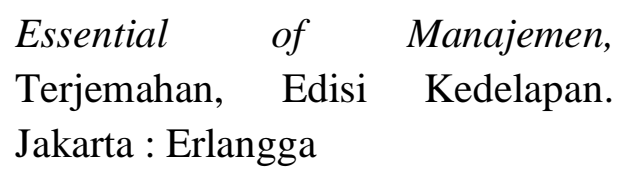

Hersey, 2004. Kunci Sukses Pemimpin Situasional. Jakarta : Delaprasata.

Heidrajrahcman dan Husnan Suad. 2002. Manajemen Personalia. Yogyakarta : BPFE.

Handoko, T. Hani, 2003. Manajemen Personalia dan sumber Daya Manusia

Edisi 2. Jakarta: PT. Gramedia Pustaka Utama

Haryono, Siswoyo, 2007. Statistika Penelitian Manajemen dengan Program SPPS. UTP: Program Pascasarjana Manajemen.

Handoko, TH, 2007. Mengukur Kepuasan Kerja. Jakarta : Erlangga

Indriantoro,N. Dan Supomo, B. 2013. Metodologi Penelitian Bisnis untuk Akuntansi dan Manajemen. Yogyakarta :Fakultas Ekonomika dan Bisnis UGM.

Jogiyanto dan Abdillah, W. 2009. Konsep dan Aplikasi PLS (Partial Lest Square).Yogyakarta:BPFE.
Kartono, Kartini. 2005. Pemimpin dan Kepemimpinan. Jakarta : rajawali 1998

Keran, Nugi, Kristina, 2012. Pengaruh Motivasi kerja, Kompetensi dan Kompensasi Terhadap Kinerja Karyawan di Yayasan Bintang Timur Tangerang, ejournal.bsi.ac.id>widyacipta $>$ arti cle. Di download tanggal 28 Nopember 2016.

Lumbanraja, Prihatin dan absah, Yeni, 2014. Pengaruh Gaya Kepemimpinan Dan Motivasi Terhadap Kinerja Guru Di SMP Negeri 1 Pandan, Jurnal Bisnis dan Manajemen Eksekutif vol. No.1, 2014, artikel 1, download portalgaruda.org $>$ article. Di download tanggal 30 Nopember 2016.

Malayu, SP, 1996. Manajemen Dasar Pengertian Dan Masalah. Jakarta : PT. Gunung Agung

Malayu, SP, 2005. Dasar Peningkatan Produktivitas. Jakarta: Bumi Aksara

Mangkunegara, 2001. Manajemen Sumber Daya Manusia Perusahaan. Bandung: Rosdakarya

Mangkunegara, Anwar Prabu. 2008. Perilaku dan Budaya Organisasi. Bandung: Refika Aditama.

Maryoto, Susilo. 2000. Manajemen Sumber Daya Manusia. Yogyakarta: BPFE

Mathis L. Robert, dan Jackson H.John. 2002. Manajemen Sumber Daya Manusia. Jakarta : Salemba Empat 
Nawawi, Hadari, 2003. Kepemimpinan yang Efektif, Gajah Mada Unisity Press, Yogyakarta.

Notoatmojo, 2005. Pendidikan dan Perilaku Kesehatan Edisi. Jakarta : Penerbit Rineka Cipta

Nafisah Durrotun, Raharjo Toto Susilo, 2006. Analisis Pengaruh Gaya Kepemimpinan Terhadap Kepuasan Kerja, Komitmen Organisasi Dan Kinerja Karyawan (Studi Empiris Pada Departemen Agama kabupaten kendal dan Departemen Agama Kota Semarang), Jurnal studi manajemen \& Organisasi http://ejournal.undip.ac.id/index.ph p/smo. Di download tanggal 2 Desember 2016 jam 19.00 WIB.

Prijati, Roscahyo, Agung, 2013. Pengaruh Gaya Kepemimpinan Terhadap Kinerja Karyawan Pada Rumah Sakit Siti Khodijah Sidoarjo, Jurnal Ilmu \& Riset manajemen Vol.2 No. 12

2013.https://id.scribd.com>docume nt. Di download tanggal 4 Desember 2016 Jam 16.00 WIB.

Ranupandojo, H, Suad Husnan. 2001. Manajemen Sumber Daya Manusia. Yogyakarta : BPFEUGM

Robbins, Stephen P, 2003. Perilaku Keorganisasian Jilid 1 Edisi 9. Jakarta: PT Indeks kelompok Gramedia

Robbins, Stephen P. 2006. Perilaku Organisasi. Alih bahasa : Benyamin Molan. Edisi kesepuluh. Jakarta: PT. Indeks
Ruyatnasih, 2013. Pengaruh Gaya Kepemimpinan Terhadap Kinerja Karyawan Pada Bagian Operator SPBU PT. Mitra buana Jaya Lestari Karawang, Jurnal manajemen Vol. 10, No.3 April 2013

Feunsika.ac.id $>$ uploads $>2015$. Di download tanggal 08 Desember 2016 jam 10.30 WIB,

Siagian, Sondang, 1993. Manajemen Sumber Daya Manusia. Jakarta : Bumi Aksara

Siagian, Sondang, 2003. Teori \& Praktek Kepemimpinan. Jakarta : Rineka Cipta

Somantri, Ating, dan Muhidin, Ali, Sambas, 2006. Apiklasi Statistika Dalam Penelitian. Bandung: Pustaka Setia

Sugiyono, 2005. Metode Penelitian Administrasi. Bandung : Alfabeta

Sugiyono, 2007. Metode Penelitian Bisnis, Jakarta : PT. Gramedia

Saputra, Rio. 2006. Pengaruh Gaya Kepemimpinan Dan Motivasi Terhadap produktivitas Kerja PT. Kurnia Maju Sejahtera Palembang.

Saputra, Angga, 2008. Pengaruhi disiplin kerja dan Gaya Kepemimpinan terhadap Kinerja Pegawai PT. Exa Mandiri Solusi Palembang.

Siagian, Sondang P, 2008. Manajemen Sumber Daya Manusia. Jakarta: Bumi Aksara.

Sopiah, 2008. Perilaku Organisasi. Yogyakarta: Andi Offset

State of Connecticut, www.google.com, Departement of Adminstrative 
Services Human Resources

Business center

Sujak, Abi. 2000. Manajemen Personalia, Edisi Kelima, Cetakan Pertama, Yogyakarta : BPFE

Tika, MP. 2006. Budaya Organisasi dan Peningkatan Kinerja Perusahaan.

Tintin, 2010. Pengaruh Gaya Kepemimpinan Terhadap Kinerja Pegawai Pada SBU Pos Prima Direktorat Operasi PT. Pos Indonesia (Persero), Jurnal Manajemen, Vol.9 No. 2, Mei $2010 . \quad$ Majour. maranatha.edu $>$ article $>$ download. Di download tanggal18 Januari 2017 jam 14.00 WIB.

Tampi, Johanes, Bryan, 2014. Pengaruh Gaya Kepemimpinan dan Motivasi Terhadap Kinerja Karyawan Pada PT. Bank Negara Indonesia, Tbk (Regional Sales Manado), jurnal "Acta Diurna" volume III , No. 4, tahun 2014. ejournal. unsrat. ac.id. Di download tanggal 20 januari 2017 jam. 17.00 WIB.

Tjiptono, 2006. Manajemen Sumber Daya Manusia Untuk Perusahaan : Dari Teori Ke Praktik. Jakarta : Raja Grafindo.

Umar, Husain. 2008. Metode Penelitian. Jakarta : Bumi Aksara.

Winardi, 2000. Kepemimpinan Dalam Manajemen. Jakarta : PT. Remika Cipta.

Wirawan, 2003. Teori Kepemimpinan Yayasan Bangun Indonesia dan UHAMKA PRESS, Jakarta.
Winardi, 2001. Motivasi dan Pemotivasian Dalam manajemen. Jakarta : Raja grafindo Persada

Yunus Mukhlis, Musnadi Said, Maulizar, 2012. Pengaruh Kepemimpinan Transaksional Dan Transformasional Terhadap Kinerja Karyawan Bank Syariah Mandiri Cabang Banda, Jurnal manajemen Pascasarjana Universitas Syiah Kuala. download. portalgaruda. org>article. Di download tanggal 23 Januari 2017 jam 17.30 WIB.

Yulianto, 2015. Pengaruh Gaya Kepemimpinan dan Motivasi kerja Terhadap Kinerja karyawan (Studi Kasus Pada Bank Rakyat Indonesia Cabang Surakarta), Pdf Naskah Publikasi Universitas Muhammadiyah Surakarta, eprints.ums.ac.id>NASKAH_PUB LIKASI. Di download tanggal 12 Februari 2017 jam 12.00 WIB.

Zamzam Fakhry, 2016. Pedoman Penulisan Proposal Tesis Program Magister Universitas IGM, Palembang : Noerfikri

Zamzam, Fakhry, Havis Aravik, 2016. Manajemen SDM Berbasis Syariah, Bogor : CV. RWTC Success 